
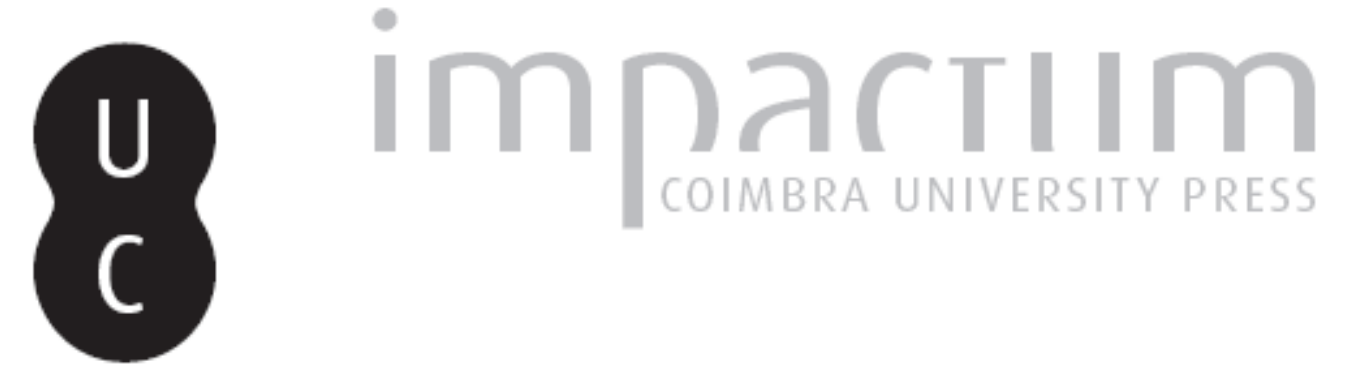

\title{
Ecumenismo e diálogo inter-religioso: algumas notas
}

Autor(es): Rodrigues, Manuel Augusto

Publicado por: $\begin{aligned} & \text { Instituto de História Económica e Social, Faculdade de Letras da } \\ & \text { Universidade de Coimbra }\end{aligned}$

URL

persistente:

URI:http://hdl.handle.net/10316.2/11963

DOI:

DOI:http://dx.doi.org/10.14195/0870-4147_40_2

Accessed : $\quad$ 26-Apr-2023 14:39:49

A navegação consulta e descarregamento dos títulos inseridos nas Bibliotecas Digitais UC Digitalis, UC Pombalina e UC Impactum, pressupõem a aceitação plena e sem reservas dos Termos e Condições de Uso destas Bibliotecas Digitais, disponíveis em https://digitalis.uc.pt/pt-pt/termos.

Conforme exposto nos referidos Termos e Condições de Uso, o descarregamento de títulos de acesso restrito requer uma licença válida de autorização devendo o utilizador aceder ao(s) documento(s) a partir de um endereço de IP da instituição detentora da supramencionada licença.

Ao utilizador é apenas permitido o descarregamento para uso pessoal, pelo que o emprego do(s) título(s) descarregado(s) para outro fim, designadamente comercial, carece de autorização do respetivo autor ou editor da obra.

Na medida em que todas as obras da UC Digitalis se encontram protegidas pelo Código do Direito de Autor e Direitos Conexos e demais legislação aplicável, toda a cópia, parcial ou total, deste documento, nos casos em que é legalmente admitida, deverá conter ou fazer-se acompanhar por este aviso.

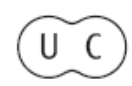



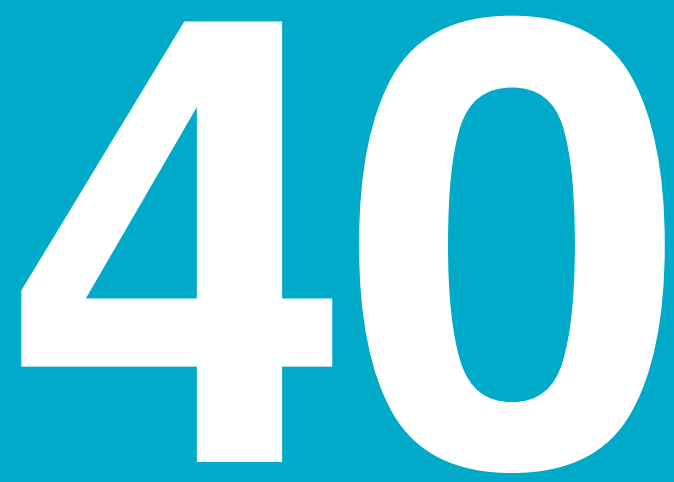

\section{Revista Portuguesa de História}

Faculdade de Letras da Universidade de Coimbra Instituto de História Económica e Social

Coimbra 08/09 
Revista Portuguesa de História

t. XL $(2008 / 2009)$

pp. $45-70$

\title{
Ecumenismo e diálogo inter-religioso. Algumas notas
}

\author{
Manuel Augusto Rodrigues \\ Universidade de Coimbra
}

\section{A Teologia no séc. XX}

No preâmbulo do seu livro La teologia del 20. secolo Rosino Gibellini escreve que Ludwig Wittgenstein no prefácio das "Observações filosóficas"1 que seriam editadas em 1964 afirmava: «Quisera dizer que este livro está escrito em honra de Deus, se estas palavras não soassem hoje vazias, quer dizer, se não fossem mal interpretadas. De facto, querem expressar que o livro foi escrito com boa vontade, e na medida em que não tivesse sido escrito com boa vontade, mas sim com vaidade ou coisa parecida, o seu autor queria sabê-lo condenado. Ele não pode purificá-lo dessa escória mais de quanto ele seja puro em si mesmo» ${ }^{2}$.

1 Philosophische Bemerkungen, Oxford, 1964.

2 Vid. Rosino Gibellini, La teologia del 20. secolo: edizione attualizzata con una Appendice: Il passo del Duemila in teologia, 6. a ed., Brescia, 2007. As “Observações filosóficas” de Ludwig Wittgenstein foram também vertidas para espanhol na cidade do México em 1997. 
Por outro lado, o teólogo evangélico Gerhard Ebeling, um dos principais expoentes da teologia hermenêutica, que cita o texto wittgensteiniano, sublinha a dor daquele filósofo porque hoje não se pode dizer abertamente que isto ou aquilo é feito «em honra de Deus» ${ }^{3}$.

No princípio do século, Ernst Troeltsch, que Harnack definiu como o maior filósofo depois de Hegel, observava: «Sem os ataques e o escárnio dos filhos do século, não existem - no terreno religioso - convencimentos, mas apenas banalidades. Mas os que praticam o escárnio distam muito de ter o monopólio do pensamento científico; o certo, melhor, é que para eles permanece fechada uma parte da realidade, e a que lhes é acessível é desejada como sendo dotada de uma plenitude, uma transparência e uma auto-suficiência maiores das que efectivamente tem» ${ }^{4}$.

E prossegue Gibellini: «o discurso teológico do séc. XX, como discurso feito «em honra de Deus», foi-se desenvolvendo cada vez mais como discurso em defesa e a favor do «Humanum». E cita Santo Ireneu: «Gloria Dei vivens homo» («a glória de Deus é o ser humano vivo»).

Num importante discurso filosófico intitulado O futuro da Ilustração (1987), a 40 anos da publicação da Dialéctica da Ilustração (1947) de Theodor Ludwig Adorno 5 e Max Horkheimer, Johann Baptist Metz, um dos principais representantes da teologia política, advertia os filósofos presentes, entre os quais se encontrava Habermas, que a cultura da ilustração, como cultura da liberdade, da democracia e dos direitos humanos, se quer ter futuro, deve abrir-se aos contributos que lhe pode oferecer a memória de Deus (Gottesgedächtnis) da tradição bíblico-cristã, «a qual ainda hoje permite falar de humanidade e de solidariedade, de opressão e de libertação, e protestar contra uma injustiça que clama ao céu» ${ }^{6}$.

3 Ebeling é autor de importantes obras como Lehre und Leben in Luthers Theologie, Opladen, 1984.

4 Ernst Troeltsch, escreveu, entre outros, Die Absolutheit des Christentums und die Religionsgeschichte: Vortrag gehalten auf der Versammlung der Freunde der Christlichen Welt zu Mühlacker am 3. Oktober 1901, Tubinga, 1929.

5 Dialektik der Aufklärung. Philosophische Fragmente, Hamburg etc., 1947; Dictionnaire de Théologie, ed. de Peter Eicher, trad. fr., Paris, 1988. A Ästhetik: (1958/59) de Adorno foi editada por Eberhard Ortland, Francoforte, 2009.

6 Vid. Hendrikus Berkhof, 200 Jahre Theologie. Ein Reiserbericht, Neukirchen-Vluyn, 1985; Sigurd Hjelde, Die Religionswissenschaft \& das Christentum. Eine historische Untersuchung über das Verhältnis von Religionswissenschaft \& Theologie, Leiden, 1994; Alex Michaels, Klassiker der Religionswissenschaft. Von Friedrich Schleiermacher bis Mircea Eliade, Munique, 1997; Giovanni Magnani, Storia comparata delle religioni. Principi fenomenologici, Assis, 1999; Gerhard Richter, Oikonomia: der Gebrauch des Wortes Oikonomia im Neuen Testament, bei den Kirchenvätern und in der theologischen Literatur bis ins 20. Jahrhundert, Berlim etc., 2005; Jürgen Habermas, Zwischen Naturalismus und Religion. Philosophische Aufsätze, Francoforte, 2005; Jürgen Habermas e Josef Ratzinger, Dialektik der Säkularisierung. Über Vernunft und Religion. Mit einem Vorwort, ed. de Florian Schuller, Friburgo, Basel, Viena 2005; David Cortright, 
$\mathrm{O}$ interessante livro de Gibellini passa em revista as diversas teologias que foram surgindo ao longo do séc. XX: a teologia dialéctica (Karl Barth), a existencial (Rudolf Bultmannn), a hermenêutica (Schleiermacher, Gadamer; Ernst Fuchs e Gerhard Ebeling), a cultural (Paul Tillich), a da modernidade (Dietrich Bonhoeffer), a da secularização (Friedrich Gogarten), a da teologia católica desde a controvérsia modernista até à viragem antropológica (Alfred Loisy, Maurice Blondel, Pierre Teilhard de Chardin, Henri de Lubac, Jean Daniélou, Marie-Dominique Chenu, Yves Congar, Romano Guardini, Karl Rahner, Hans Urs von Balthasar), a teologia da história (Oscar Cullmann, Wolfhart Pannenberg), da esperança (Jürgen Moltmann), da política (Johann Baptist Metz), da experiência (Edwar Schillebeeckx), da libertação (Gustavo Gutiérrez, Leonardo Boff, Paulo Freire, Jon Sobrino), a negra (J. Washington, J. Cone), a feminista (L. Russel), a do terceiro mundo (J.-M.Ela, e a ecuménica (Yves Congar, Oscar Cullmann, H. Fries e Karl Rahner, Hans Küng, J. Hick, Mircea Eliade, R. Panikkar).

Neste trabalho iremos limitar-nos ainda que em linhas gerais ao problema do ecumenismo e das religiões não cristãs com particular incidência no judaísmo no qual se fundamenta e radica o cristianismo como tão profundamente é analisado por S. Paulo na sua Epístola aos Romanos?.

Peace: a history of movements and ideas, 3. ${ }^{a}$ ed., Cambridge etc., 2009; Hans-Ulrich Wiese, Prophetische Gestalten im 20. Jahrhundert, Kevelaer, 2009; Hans-Richard Reuter (ed.), "Frieden - Einsichten für das 21. Jahrhundert: 12. Dietrich-Bonhoeffer-Vorlesung; Juni 2008", in Münster, Kongress: Dietrich-BonhoefferVorlesung, Berlim etc., 2009.

7 Numa população global calculada em sete biliões de pessoas, o Cristianismo é a primeira religião com cerca de $30 \%$ de cristãos em todo o mundo: mais de 2, 6 biliões de aderentes; divide-se em três ramos principais: o católico (1, 2 bilião), o protestante (500 milhões) e o ortodoxo (300 milhões). - O Islão que é a segunda religião com cerca de $15 \%$ de adeptos (1,3 bilião) está muito presente na Ásia, Médio Oriente, África e também na Europa. A Indonésia é o país com maior número de muçulmanos. A grande divisão no Islão é entre sunitas e chiitas. - O Hinduísmo constitui a terceira religião com mais de 1 bilião de praticantes na sua maioria na Índia, Nepal e Bangladesh. - Outras religiões indianas são o Jainismo (3 a 4 milhões), o Sikismo (27 milhões) e o Zoroastrismo. - O Budismo conta com 325 milhões de crentes, nomeadamente no Sri-Lanka, Ásia sudeste e Tibet. - O Confucianismo e o Taoísmo são filosofias e religiões populares da China e agrupam cerca de 230 milhões de adeptos. - O Taoísmo é uma mistura do culto dos espíritos da natureza e dos antepassados, dos princípios de Lao-Tsé e de crenças diversas. - O Confucianismo é uma filosofia moral e política baseada em Confúcio. - O Judaísmo conta cerca de 15 milhões de adeptos não só em Israel mas também, essencialmente, na Europa e América do Norte. - Há ainda os ateus e os agnósticos (150 e 900 milhões). - Vid. Hubert Jedin et alii (ed.), Atlas zur Kirchengeschichte. Die christlichen Kirchen in Geschichte und Gegenwart, ed. actualizada, Friburgo-Basileia-Roma-Viena, 1987; Antoine Sfeir, Atlas des Religions, Paris, 1994; John Bopwker, Religions du monde, Londres, 1997; Günter Kettermann, Atlas zur Geschichte des Islam, com introdução de Adel Theodor Khoury, Darmstadt, 2001; Encyclopédie des Religions (dir. Giuseppe Annoscia et alii), Paris, 2002. 


\section{Ortodoxia e reforma}

Comecemos por apresentar alguns dados sobre a Ortodoxia e a Reforma que ocupam lugar importante na questão do ecumenismo. Dá-se o nome de Ortodoxia ${ }^{8}$ às Igrejas orientais ou ortodoxas, uniatas e católicas do Oriente. As Igrejas orientais do Próximo Oriente, da Europa de Leste e da Índia meridional distinguem-se da latina por conservarem liturgias particulares e instituições antigas, testemunhos dos primeiros séculos do cristianismo; também são conhecidas por Igrejas pré-calcedónias (fundadas antes do concílio de Calcedónia, 451). As que se juntaram a Roma passaram a chamar-se uniatas conservando a tradição litúrgica bizantina.

As Igrejas orientais católicas são a síria oriental, chamada nestoriana, a arménia, a síria ocidental chamada jabobita e a copta.

A ortodoxia é o conjunto das Igrejas orientais, autocéfalas, separadas de Roma, depois de 1054. Cada Igreja ortodoxa é independente na sua administração, mas está em comunhão com as outras (a colegialidade) e reconhece o primado honorífico do patriarcado de Constantinopla. Este conjunto é composto de quatro antigos patriarcados e de uma quinzena de Igrejas locais autocéfalas. A maior parte usa o rito bizantino, herdado de S. Basílio e de S. João Crisóstomo.

A fé ortodoxa está fundada nas definições dogmáticas dos sete primeiros concílios ecuménicos, até ao de Niceia II em 787. O papa de Roma é reconhecido como patriarca mas o primado é-lhe recusado. A ruptura com a Igreja latina teve razões culturais e hierárquicas: o primado de Roma, a natureza do pão eucarístico e o casamento dos sacerdotes, e secundariamente, questões teológicas em que sobressai o Filioque. Após 1965, os anátemas e excomunhões recíprocos que criaram o cisma de 1054 foram retirados. Todas as Igrejas ortodoxas fazem parte, juntamente com as igrejas protestantes, do Conselho Ecuménico das Igrejas, criado em 1948.

Os patriarcados ortodoxos são os quatro antigos: Constantinopla, Alexandria, Antioquia e Jerusalém. Há ainda cinco patriarcados recentes: Rússia, Sérvia, Roménia, Bulgária e Geórgia. E mais diversas Igrejas: Chipre, Grécia, Roménia, Polónia, Albânia, Estados Unidos, etc.

A Reforma protestante com os princípios sola fides e sola scriptura designa o movimento religioso nascido com Lutero, e continuado por outros como Calvino

8 R. Janin, Les Églises orientales et les rites orientaux, Paris, 1970; J. Hajjar, Le Vatican - La France et le Catholicisme Oriental (1878-1914). Diplomatie et Histoire de l'Église, Paris, 1979; Pierre Maraval, Lieux saints et pèlerinages d'Orient, Paris, 1985; P. Evdokimov, L'Orthodoxie, Paris, 1990; Claude Lorieux, Chrétiens d'Orient en terrres d'islam, Paris, 2001; Seraphim Rose, Orthodoxie und die Religion der Zukunft, trad. do ingl., Straelen, 2009. 
(1509-1564). O centenário do seu nascimento tem sido evocado com vários actos. A tradução da Bíblia para alemão e posta em uso na liturgia revestiu-se de grande significado em contraste com os católicos que se mantinham fiéis à Vulgata de S. Jerónimo. A Reforma contou até aos nossos dias com teólogos de grande envergadura como Melanchton (1497-1560), Bayle (1647-1706), Schleiermacher (1768-1834), Dilthey (1833-1911), Bonhoeffer (1906-1945), Tillich (1886-1965), Karl Barth (1886-1968), Bultmann (1884-1876).

Seguiram-se várias divisões e guerras religiosas a que pôs termo o Edito de Nantes (1598) que viria a ser revogado pelo edito de Fontainebleau em 1685 por Luís XIV que defendeu a Igreja de Estado.

O anglicanismo é a Igreja reformada de Inglaterra. Os anátemas contra a Igreja anglicana foram levantados pelo papa Paulo VI e pelo patriarca Atenágoras I em 7 de Dezembro de 1965. O papa Bento XVI na constituição apostólica Anglicanorum Coetibus, de 9 der Novembro de 2009, aborda a questão da instituição de ordinariados pessoais para os anglicanos que entram em plena comunhão com a Igreja Católica.

O concílio de Trento e a Contra-Reforma constituíram a resposta católica à Reforma protestante, mas ao mesmo tempo deram origem a uma intensificação da reforma da Igreja: ordens religiosas, criação de seminários, pregação, etc. Sobressaíram na primeira fase teólogos importantes como Francisco Suárez (1548-1617), Luís de Molina (1535-1601), Antoine Arnauld (1612-1694) e Afonso de Ligória (1696-1787). E assistiu-se a uma verdadeira explosão de comentários bíblicos, muitos deles de tendência apologética.

O termo alemão Gegenreformazion foi criado em 1776 pelo jurista J. S. Püttner par designar o retorno pela força à prática católica dum território que se havia tornado protestante. É o período tridentino e pós-tridentino da Igreja católica que vai até 1700 , com lutas terríveis com os protestantes pelo meio.

\section{Polémica com os judeus ${ }^{9}$}

Desde as origens do cristianismo que a atitude anti-semita se manifestou quer nas Igrejas orientais quer na ocidental. Com a paz de Constantino (313) tinha início uma nova fase da história do cristianismo tornado religião oficial

9 Vid. Abraham Heschel, God in search of Man (A philosophy of Judaism), N. Y., 1955; Hans Küng, Josef van Ess-Heinrich von Stietencron-Heinz Bechert, Christentum und Weltreligionen. Islam, Hinduismus, Budhismus, 1984; Hans Küng, Das Judentum, 1991; Dictionnaire Encyclopédique du Judä̈sme (dir. de G. Wigoder), Paris, 1993; Hans Küng, Das Christentum. Wesen und Geschichte, 1994; Id., Der Islam, 3. ${ }^{\mathrm{a}}$ ed., 2004; Gilbert Dahan, L'exégèse chrétienne de la Bible en Occident médiéval XIIe-XIV siècle, Paris, 1999; e as várias enciclopédias judaicas. 
do estado com sede em Constantinopla. O estatuto dos Hebreus sofreu ao longo dos tempos uma quase constante oposição da sociedade, incluindo a Igreja, até se chegar à Shoah em que cerca de seis milhões de Judeus foram tragicamente exterminados.

O conteúdo da polémica anti-judaica era o argumento profético, o facto da existência da Igreja, a necessidade de disposições morais, o abandono da Lei, a Trindade, o messianismo e a vida e a morte de Jesus Cristo. Encontramos frequentemente os nomes disputatio, altercatio, refutatio, reprobatio. Recordem-se os nomes de $\mathrm{S}$. Jerónimo em vários dos seus escritos e que traduziu a Bíblia ad confuntandos Judaeos etiam per ipsa exemplaria quae ipsi verissima confitentur, ut, si quando adversum eos christianis disputatio est non habeant subterfugiendi diverticula sed suomet potissimum mucrone feriantur $\mathrm{r}^{10}$; de Santo Agostinho no Tractatus adversus Judaeos ${ }^{11}$; e de Gilbert Crispin na sua Disputatio judaei cum christiano de fide christiana ${ }^{12}$. No séc. VII, temos Santo Isidoro de Sevilha, e Santo Ildefonso e S. Julião de Toledo.

Mas também houve escritos cristãos de Judeus convertidos ao cristianismo: Samuel de Fez e Pedro Afonso (séc. XII); Paulo Christiani (séc. XIII), Afonso de Valladolid (séc. XIV), Jerónimo de Santa Fé, Paulo de Burgos ou de Santa Maria, Afonso de Spina (séc. XV), etc.

De 1500 a 1789, os escritos aumentam graças à tipografia para cuja divulgação o contributo hebraico foi decisivo. No Ocidente temos Fino Fini e Luís Vives, este com o seu De veritate fidei christianae libri quinque contra ethnicos, Judaeos, Agarenos sive mahometanos et perverse christianos (Basileia, 1543); Gilbert Génébrad, da ordem de Cluny, com Contra R. Josephum Albonensem, $R$. Davidem Kimchium et alium quemdam judaeum anonymum nonnullos fide $i$ christianae articulos oppugnantes (Paris, 1566); e François Carboni, editor de Flagellum Hebraeorum de Inghetto Contrario.

Merece ser referida a dimensão polémica do lado cristão nos grandes debates públicos de Paris (1240), Barcelona (1263) e Tortosa (1413-1414) com judeus.

Alfonso de Zamora, convertido em 1501, foi encarregado da correcção do texto hebraico da Poliglota de Alcalá e escreveu Epistola ad infideles Hebraeos Urbis Romae na sua Introductio artis grammaticae hebraicae (Alcalá, 1526).

${ }^{10}$ Apologia adversus libros Rufini, 1. III, c. XXV; cf. também 1. II, c. XXIV-XXXV; P. L., t. XXIII, col. 476, 447-456.

11 P. L., t. XLII, col. 51-64.

12 P. L., t. CLIX, col. 1005-1030. 
Nunca é demais salientar a importância dos autores judeus para o estudo do idioma hebraico e da exegese bíblica. Lembramos alguns: Rashi (1040-1105), David Kimchi (+ ca. 1235), Maimónides (1135-1204) e Isaac Abravanel (1437-1508). Sanctes Pagnino (+ 1541) e Sixto de Siena (+ 1569) muito ficaram a dever aos trabalhos filológicos e escriturísticos dos escritores hebreus medievais $^{13}$.

Entre nós, nos sécs. XVI-XVII os dois primeiros escritos a trazer como tema principal a questão dos judeus são o Espelho de cristãos-novos e convertidos (1541) do cisterciense Francisco Machado e o Diálogo evangélico sobre os artigos da fé contra o Talmude dos judeus (1542-45) de João de Barros. No entanto esses dois tratados não receberam autorização para ser impressos, visto que a concepção de um cristianismo evangelizador e não persecutório neles formulada não era do agrado do poder real, bastante enraizado na época por D. João III que era hostil aos cristãos-novos. Surgem depois Vicente da Costa Matos com Breve discurso contra a perfídia herética do judaísmo (Lisboa, 1622) ${ }^{14}$ e o carmelita Timóteo de Ciabra Pimentel com La honda de Davido a cinco sermones del Santíssimo Sacramento contra los judíos (Roma, 1631) ${ }^{15}$.

O Padre António Vieira aparece como o grande paladino da defesa da causa judaica e dos cristãos novos.

No séc. XVIII, destacaram-se o dominicano Louis Gotti, François-Ilharat de la Chambre e Statler, autor de Démonstration évangélique ou certitude de la religion révélée par Jesus-Christ démontrée contre tous les philosophes antichrétiens anciens et modernes, contre les Juifs et les mahométans; e ainda Jean Bernard de'Rossi com obra Della vana aspettazione degli Ebrei del loro re Messia (Parma, 1773), Laberthonie e Beurier. A polémica prosseguiu nos sécs. XVII-XVIII.

Entre os escritos protestantes salientam-se os de Lutero ${ }^{16}$ e de Calvino; e de Sebastian Münster no seu Colloquium cum judaeo pertinaciter suis de Messia opinionibus addictio, em hebraico e em latim (Basileia, 1539), de Teodoro Bibliander (Buchmann) em De Judaeorum et christianorum defectione a Christo, Ecclesia et fide catholica (Basileia, 1553) e du Plessis-Mournay.

13 Vid. Bible de tous les temps, vol. 4: Le Moyen Age et la Bible, dir. de Pierre Riché e Guy Lobrichon, Paris, 1984; Gilbert Dahan, op. cit.

14 Vicente da Costa Matos, natural de Lisboa, que era muito versado na erudição sagrada segundo Barbosa Machado, escreveu ainda Honras christãs nas afrontas de Jesu Christo, e segunda parte do primeiro discurso contra a heretica perfidia do judaísmo, Lisboa, 1625.

15 Sobre Ciabra Pimentel, vid. Barbosa Machado, Bibliotheca Lusitana, Coimbra, 1966, t. 3, p. 761-762.

16 O documento principal do anti-semitismo de Lutero é Von den Juden und ihren Lügen (1543). 
No séc. XVII sobressaiu Jean Buxtorf (pai) com o livro Ad quaestiones et objecta judaei cuiusdam et responsa christiani, escrito depois da Synagoga judaica (Basileia, 1641). No séc. XVIII, surgiram Jean Jacques Schudtt, Charles Lesley e Stanhope.

De salientar os escritos sobre a utilização dos livros judaicos que muito beneficiaram do movimento da Renascença. Leão X subvencionou Judeus convertidos para se ocuparem de os traduzir. Por exemplo, interessou-se com a publicação do Talmud ${ }^{17}$.

Um estudioso que muito enalteceu a cultura hebraica foi Johannes Reuchlin com o seu De verbo mirifico (Basileia, 1494) e Der Augenspiegel (1511); o mesmo se diga de Pierre Colonna ou Galatinus, Paul Ricci e Jules Bartolocci de Celleno com a sua Bibliotheca magna rabbinica, 4 vols. (Roma, 1675-1693), que se serviram largamente da literatura judaica ${ }^{18}$.

Mas não faltaram autores que se insurgiram contra os livros dos Judeus. O caso mais célebre foi o de Jean Pfefferkorn, judeu convertido com as obras contra Reuchlin Der Judenspiegel (1507), Der Judenfeind e Der Handspiegel (1511); e o inquisidor dominicano Jacques Hochstratten com a Destructio cabbalae seu cabbalistiae perfidiae (Colónia, 1519).

Havia é certo um ambiente irénico, porém sobressaía a ideia de conversão e o processo inquisitorial dominava. As leis imperiais e as encíclicas papais e outros documentos eclesiásticos, a inquisição e os sermões em autos de fé, para só falar de alguns factos, continham, salvo raras excepções, determinações muito duras contra os Judeus.

Mas não é de esquecer a série de tentativas de diálogo ao longo da história, desde os diálogos de Justino com Trifão no séc. II até ao debate tido entre Karl Ludwig Schmidt e Martin Buber no séc. XX. Ou ainda a altercatio de Simon e de Teófilo (séc. V) ou a disputatio do clérigo de Westminster do séc.

17 Entre as edições do Talmud de Jerusalém referimos: as de Veneza (Bomberg), 1523-24, de Cracóvia, 1609, de Krotoshin, 1866, de Zhitomir, 1860-67, de Piotrkow, 1900-1902, e a versão francesa de M. Schwab, 11 vols., Paris, 1879-80; vol. 12, 1890. - Vários tratados foram editados com versão latina: Ugolini, autor de Thesaurus antiquitatum sacrarum, vols. XVII-XXX, Veneza, 1755-65; e com tradução alemã Wunsche, Der palästinische Talmud in seinen haggadischen Bestandteilen ins Deutsche übersetzt” (Zurique, 1880).

${ }^{18}$ Reuchlin (1455-1522) notabilizou-se como prestigiado hebraísta. Foi o primeiro cristão que escreveu, em 1506, uma gramática hebraica. Por isso é conhecido pelo epíteto de pai da hebraística cristã. Foi lido e estudado posteriormente por historiadores como Ludwig Geiger. Tornou-se professor em Heidelberg. Apesar de cristão, foi influenciado pela Cabala, como sucedeu com Pico de la Mirandola. Deste modo, o Zohar, a incorporação da Cabala, entrou em voga nos sistemas de todos os místicos do século XVI. Reuchlin escreveu no seu livro De Arte Cabbalistica: "O meu professor Pitágoras, o pai da filosofia, tomou seus ensinamentos dos Kabbalistas... ele foi o primeiro a traduzir a palavra Kabbalah, desconhecida de seus contemporâneos, para a palavra grega filosofia... a Kabbalah não nos permite viver as nossas vidas no pó, mas eleva as nossas mentes à altura do conhecimento". 
XII. Sobressaíam os argumentos bíblicos ou racionais a fim de contradizer o interlocutor.

A Alemanha foi o teatro de várias confrontações como a de Moses Mendelssohn ${ }^{19}$ e, em 1769, do suíço Johann Kaspar Lavater (1741-1801).

Em 1916 teve lugar a troca de cartas entre Franz Rosenzweig ${ }^{20}$ e Eugen Rosenstock-Huessy ${ }^{21}$, ele mesmo um convertido. Os judeus eram obrigados a participar nestes exercícios e jogavam aí a sua vida.

No que toca ao Islão, lembramos a dialexis de João Damasceno (s. VIII) e a refutatio de Nicétas (s. XII) contra o Corão e a religião muçulmana. Surgiu depois uma teologia científica (kalám) que propunha a verdade islâmica em bases filosóficas. Pedro Venerável, Raimundo Lullo, Raimundo Martí, Ricoldo de Monte Croce e S. Tomás na Suma contra Gentiles tentaram rebater a crença muçulmana.

Eis alguns exemplos: Raimundo Lullo (1235-1315) com as suas disputationes, Ricoldo da Monte Croce (1243-1320) com a reprobatio que lhe é atribuída; e ainda o cartuxo Dinis (Cartusiano) com o seu dialogus disputationis; foi contemporâneo de Nicolau de Cusa, autor dos livros De concordantia catholica e De pace fidei (1434) ${ }^{22}$. Mais tarde Erasmo no seu De querela pacis e noutras obras surge como grande defensor do irenismo.

${ }^{19}$ Moisés Mendelssohn (1729-1786), filósofo e rabino judéo-alemão, é considerado o precursor da Haskalá, ou seja, da Renascença Judaica na Europa. Seu pai chamava-se Mendels, tendo tomado mais tarde o nome de Mendelssohn ("filho de Mendel"). Foi uma figura de referência do judaísmo do século XVIII, associada ao iluminismo. Para alguns ele foi o terceiro Moisés (os outros dois foram o criador da lei bíblica e Moisés Maimónides) com quem uma nova era foi aberta para o povo judaico. Para outros ele representa um passo no início da assimilação e perda de identidade associada ao judaísmo tradicional. Mendelssohn é considerado o pai do judaísmo reformista.

${ }^{20}$ Franz Rosenzweig (1886-1929) é um dos mais notáveis filósofos-teólogos judeus do século XX. Influenciou importantes pensadores como Walter Benjamin e Emmanuel Lévinas, entre outros. A obra prima de Rosenzweig é “A estrela da Redenção" (Der Stern der Erlösung). Nela Rosenzweig analisa a unicidade de cada ser humano, a realidade do mundo e a transcendência de Deus que põem em xeque a ideia de totalidade, mostrando como estas três singularidades encontram sentido uma em relação à outra. A criação religa o mundo a Deus, a revelação permite que o ser humano seja orientado pela Palavra divina e a Redenção tem a tarefa de salvar o mundo, essencialmente pelo amor.

${ }^{21}$ Eugen Rosenstock-Huessy (1888-1973) foi um pensador, historiador, jurista, filólogo e linguista alemão. De origem judaica, converteu-se ao protestantismo aos dezasseis anos e foi um dos principais pensadores religiosos do séc. XX. A sua obra está erigida sobre o carácter sacramental da linguagem, estabelecendo os princípios do seu método gramatical e abrangendo a totalidade das ciências humanas. Destaca-se na sua obra o trabalho Angewandte Seelenkunde ou "Conhecimento prático da Alma" (1924), no qual esboçou, pela primeira vez, um método radicalmente novo para as ciências sociais, baseado na linguagem, na palavra falada e na abordagem gramatical. Esse método está presente nas suas principais obras subsequentes.

22 Traduzido para português com o título A paz da fé; seguida de Carta a João de Segóvia, acompanhada de uma introdução, por João Maria André, 2. ${ }^{\text {e }}$., Coimbra, 2009. 
De recordar também Guillaume Postel com a sua notável De orbis terrae Concordia (1554) sobre a harmonia na terra de uma religião universal: todas as religiões deviam converter-se ao cristianismo ${ }^{23}$.

Do lado muçulmano também se fez sentir aqui e além a mesma vontade de converter os outros à sua crença. Como escreve Jean-Claude Bosset no seu livro Le dialogue interreligieux. Histoire et aventure (Paris, 1996) a forma dialogal destas obras não vai além do artifício literário, ao contrário dos autênticos encontros em que a polémica é mais atenuada. Não houve então encontro construtivo antes do s. XX? O espírito da época era de polémica, de apologética e de guerra ${ }^{24}$. Mesmo o corpus de Cluny, parcialmente editado no tempo da Reforma por Bibliander ${ }^{25}$ tinha como fim a refutação do Corão e da tradição muçulmana.

A Igreja procurou inculcar o ensino da língua árabe entre os intelectuais cristãos para poderem enfrentar a polémica. O concílio de Viena (1311-1312) contém essa determinação. Intensificou-se o debate desde a Renascença com a ameaça de o Islão conquistar o Ocidente depois da guerra contra os Turcos e da queda de Constantinopla (1453).

Avançando no tempo, salientamos mais tarde o aparecimento em Paris do Comité Chrétien d'Entente France-Islam em 1947 e em 1954, em Roma, do Centro Oriente-Occidente.

De referir ainda as missões cristãs e, depois de Francisco de Assis na Idade Média, já perto de nós o nome de Ch.-M. A. Lavigerie e os padres brancos; e ainda Charles de Foucauld e Louis Massignon ${ }^{26}$. Em Roma funcionam

${ }^{23}$ Guillaume Postel (1510-1581), linguista francês, astrónomo, cabalista, diplomata, professor e universalista religioso, foi um grande estudioso dos idiomas árabe, hebraico e siríaco, e do latim e grego.

24 Vid. Les religions et la guerre, dir. de Pierre Viaud, Paris, 1991.

25 Theodore Bibliander (1506-1564), orientalista suíço, discípulo de Johannes Oekolampad e de Konrad Pelikan, grande conhecedor do hebraico, do latim e do árabe e reputado teólogo, publicou uma gramática de hebraico em 1535 e a primeira edição impressa do Corão (Basileia, 1543) durante a primeira fase da Reforma com o título Machumetis Saracenorum Principis, eiusque successorum vitae, ac doctrina, ipseqve Alcoran: quo uelut authentico legum diuinarum codice Agareni \& Turcae, alijq[ue] Christo aduersantes populi regu[n]tur, quae ante annos CCCC ...D. Petrus Abbas Cluniacensis per uiros eruditos ...ex Arabica lingua in Latinam transferri curauit: his adiunctae sunt confutationes multorum, \& quidem. probatissimorum authorum, Arabum, Graecorum, \& Latinorum, una cum ... Philippi Melanchthonis praemonitione ....: adiunctae sunt etiam, Turcaru[m] ... res gestae maxime memorabiles, a DCCCC annis ad nostra usuq[ue] tempora: haec omnia in unum uolumen redacta sunt. A terceira tradução é de 1691-1698, levada a cabo por Ludovico Marracci.

A primeira versão manuscrita (1141-1143) foi feita sob os auspícios de Pedro o Venerável por um grupo de trabalho dirigido por Robert de Ketton conhecido como Lex Mahumet pseudoprophete; a segunda tradução (ca. 1193-1216) foi realizada por Marcos de Toledo.

${ }^{26}$ Louis Massignon (1883-1962), estudioso francês do Islão e da sua história, muito contribuiu para que o Ocidente conhecesse melhor a religião muçulmana. - Vid. Jean Morillon, Massignon, Paris, 1964; Seyyed 
actualmente o Pontifício Instituto de Estudos Islâmicos e Árabes e no Cairo o Instituto Dominicano do Cairo de Estudos Orientais que têm estabelecido um diálogo frutuoso com o Islão.

E há a mencionar encontros religiosos na China entre os discípulos de Confúcio e os de Lao-tsé (também conhecido por Lao Zi, Laozi, Lao Tzu, Lao Tsé, Lao Tzi, Lao Tseu ou Lao Tze) que foi um famoso filósofo e a obra dum pensador taoísta convertido Mou-tseu.

$\mathrm{Na}$ Índia temos na corte dos imperadores Ashoka (séc. III a. C.) e mais ainda na de Akbar (séc. XVI) reuniões de muçulmanos de diferentes obediências com hindus, jainitas e cristãos.

Entre os Khazares lembramos o diálogo entre o Don e a Volga, por ocasião da sua conversão à fé judaica no séc. VIII, depois de se ter confrontado com representantes cristãos, muçulmanos e judeus.

Também houve diálogos em Bagdad e Córdova a convite dos muçulmanos com cristãos e judeus; vários destes encontros atestam uma abertura real e uma preocupação séria de conhecer a fé do outro, como aquele que teve lugar na corte abássida, em 781-782, entre o califa al-Mahdi e o "catholicos" Timóteo I. No fim vem a parábola da pérola (três anéis) que mais tarde aparece em Lessing $^{27}$.

As missões cristãs foram um terreno propício para a conversão e para um melhor conhecimento de outras culturas e religiões: os casos de Matteo Ricci (1552-1610) na China e de Roberto de Nobili (1577-1656) na Índia são disso exemplo $^{28}$. Francisco Xavier (1506-1552) escrevia numa carta do Japão, datada de 5 de Novembro de 1549:

Hossein Nasr, in Commemoration of Louis Massignon: Catholic, Scholar, Islamist and Mystic, University of Boston, November 18, 1983; e em Présence de Louis Massignon-Hommages et témoinages, Paris, 1987; Mary Louise Gude, Louis Massignon - The Crucible of Compassion, Notre Dame, Indiana, 1996; Missionary of Africa Father Maurice Borrmans: "Aspects Théologiques de la Pensée de Louis Massignon sur l'Islam”, in: Louis Massignon et le dialogue des cultures, Paris, 1996; Georges Anawati, "Louis Massignon et le dialogue islamo-chrétien", ibidem, Paris, 1996; Jean-François Six, Le grand rêve de Charles de Foucauld et Louis Massignon, Paris, 2008; Louis Massignon, Écrits mémorables. Textes établis, présentés et annotés sous la direction de Christian Jambet, 2 vols., Paris, 2009; Maurice Borrmans, Prophètes du dialogue islamo-chrétien: Louis Massignon, Jean Mohammed Abd-el-Jalil, Louis Gardet, Georges C. Anawati, Paris, 2009.

27 G. Lessing, Nathan le Sage, Paris, 1939, p. 154-163.

28 Matteo Ricci (Maccerata, 1552-Pequim, 11 de Maio de 1610), sacerdote jesuíta, cartógrafo italiano. é conhecido pela sua actividade missionária na China da dinastia Ming, onde era conhecido por Lì Mădòu (利瑪實). Atribui-se a Ricci a introdução do cristianismo na China. Recebeu a sua primeira formação na cidade natal, partindo depois para Roma onde estudou Humanidades, Leis e Ciências. A 15 de Agosto de 1571 ingressou na Companhia de Jesus. No Colégio Romano estudou Teologia e Filosofia, ao mesmo tempo que se dedicou ao estudo de Astronomia e das Matemáticas. Aconselhado pelo padre Alexandre Valignano, visitador da Companhia nas missões da Índia e do Japão, partiu para o Oriente. No Verão de 1583, juntamente com o padre Miguel Ruggieri, penetrou no Império Celeste. Vestia-se à chinesa, observando os ritos e costumes 
«Falei muitas vezes com vários bonzos eruditos, em particular um deles que todos aqui têm em alta estima, tanto pela sua sabedoria, sua vida e a sua posição social como pela sua idade avançada de 80 anos. Chama-se Ninshitsu, o que quer dizer em japonês «o coração da verdade». Ele vive entre eles como um bispo, e se ele está à altura do seu nome, é verdadeiramente um homem abençoado. Em numerosas conversações que tive com ele, encontrei-o indeciso e incerto quanto à imortalidade da nossa alma ou da nossa morte com o corpo. Muitas vezes, ele diria «sim», mas por outro lado diria «não». Tenho medo que os outros monges eruditos sejam como ele. Mas é maravilhoso até que ponto este homem é para mim um amigo próximo» ${ }^{29}$.

Mais tarde, as missões protestantes multiplicaram os contactos com os crentes de outras tradições, não só para os evangelizar mas também para os ajudar a traduzir a Bíblia para as suas línguas. Entre nós temos João Ferreira de Almeida (1628-1691), pastor protestante na Ilha de Java, autor da primeira Bíblia do Novo Testamento (Amsterdão, 1681) em português. Não concluiu o Antigo Testamento, pois veio a falecer quando traduzia o último capítulo de Ezequiel. Coube ao seu amigo Jacobus op den Akker completar a tradução em 1694. A outra versão portuguesa da Bíblia deve-se a António Pereira de Figueiredo (1725-1797). Como missionários entre os muçulmanos e outras religiões, podemos citar na Índia e Pérsia os nomes de William Carey (1761-1834) em Calcutá que verteu a Sagrada Escritura para bengali, sânscrito, e inúmeras outras línguas e dialectos; e de Henry Martyn (1781-1813), tradutor do Novo Testamento para urdu, persa e judéo-persa; e os Salmos para persa ${ }^{30}$.

chineses que não colidiam com o dogma católico. Depois de assegurar a eficácia do seu apostolado, decidiu atingir Pequim, para poder irradiar o Cristianismo a partir desta grande cidade à qual chegou a 7 de Setembro de 1595. Matteo Ricci captou a simpatia do imperador com os seus livros e saber. A questão dos ritos viria a ser de grande relevância relativamente à introdução de elementos indígenas no seio do cristianismo. A efeméride da sua morte já começou a ser evocada. Ricci é autor de vários livros. - Vid. J. Sebes, art. Ricci, Matteo, in Diccionario Histórico de la Compañia de Jesus, Roma-Madrid, 2001, vol. IV, 3351-3353.

${ }^{29}$ Ed. de G. Schurhammer e J. Vicki, Epistolae S. Francisci Xaverii, Roma, 1945, vol. 2, p. 189-190.

${ }^{30}$ Sobre João Ferreira de Almeida, vid. Herculano Alves, História da Bíblia em Portugal, Coimbra, 2000; Id., A Bíblia de João Ferreira Annes d'Almeida, Salamanca, 2005; Bíblia ilustrada, trad. de João Ferreira Annes d'Almeida, apresentação e fixação do texto por José Tolentino Mendonça, Lisboa, 2006. - William Carey (1761-1834), ministro evangelista baptista, missionário, conhecido como o "pai das missões modernas", foi um dos fundadores da Sociedade Batista Missionária nos Estados Unidos. Como missionário na colónia dinamarquesa de Serampore, Índia, evangelizou e fundou várias escolas. Henry Martyn (1781-1812) foi um presbítero e missionário anglicano em terras da Índia e da Pérsia. 


\section{Movimentos renovadores no seio do catolicismo ${ }^{31}$}

Não se pode compreender o extraordinário impulso dado ao estudo do ecumenismo e da história das religiões sem termos em consideração a verdadeira explosão de alguns movimentos renovadores que se fizeram sentir a partir do séc. XIX ${ }^{32}$.

Comecemos pelo movimento bíblico. Se atendermos às decisões do magistério eclesiástico, verificamos que o Enchiridion Biblicum de 30 pp antes de 1890 passou agora na sua nova edição para 1812 pp. ${ }^{33}$, o que é altamente revelador. A primeira intervenção importante no campo bíblico foi a de Leão XIII com a encíclica Providentissimus Deus (1893). Em 1902, era criada a Pontifícia Comissão Bíblica; e diversas foram as respostas da Comissão Bíblica entre 1904-14 ${ }^{34}$.

Em 1907, aparecem a encíclica Pascendi de Pio IX contra o modernismo e o decreto Lamentabili com 65 proposições condenadas pela Igreja; de realçar a proposta de revisão da Vulgata (1907) e a criação do Pontifício Instituto Bíblico em 1909 pela carta apostólica Vinea electa. Nesta instituição destacaram-se diversos professores ilustres como Alberto Vaccari e Agostino Bea ${ }^{35}$. Comemorou-se este ano o centenário desta importante instituição.

A Escola Bíblica e Arqueológica de Jerusalém foi criada em 1890 por MarieJoseph Lagrange (1855-1938.

Outra encíclica importante sobre os estudos bíblicos é a Spiritus Paraclitus do papa Bento XV dedicada a evocar S. Jerónimo, de 15 de Setembro de 1920.

${ }^{31}$ Sobre este ponto, vid. Evangelista Vilanova, Historia de la teología cristiana, Barcelona, 1989, vol. 3, p. 849-894.

32 O livro citado de Evangelista Villanova trata da era da razão no seu começo, das Luzes e da sua problemática teológica, do romantismo à restauração, do período que vai do Vaticano I ao Vaticano II, concluindo com balanço e perspectiva (a teologia católica nos primeiros trinta anos da fase pós-conciliar).

${ }^{33}$ Heinrich Denzinger, Enchiridion symbolorum, definitionum et declaratioum de rebus fidei et morum. Kompendium der Glaubens-bekennntnisse und kirchlichen Lehrentscheidungen. Lateinisch-Deutsch, ed. de Peter Hünermann, 40. ${ }^{a}$ ed., Friburgo-Basileia-Viena, 2005. Heinrich Joseph Dominicus Denzinger (1819-1883) foi um dos pioneiros da teologia positiva e da dogmática histórica na linha de Johann Adam Moehler e de Döllinger (1799-1890): em vez da especulação filosófica do dogma há que trabalhar na evolução histórica da teologia.

${ }^{34}$ Mencionamos os três últimos documentos emanados da Pontifícia Comissão Bíblica: L'interprétation de la Bible dans l'Église, L'interpretazione della Bibbia nella Chiesa (15 de Abril de 1993); Le peuple juif et ses Saintes Écritures dans la Bible chrétienne, Il popolo ebraico e le sue Sacre Scritture nella Bibbia cristiana (24 de Maio de 2001); e Bibbia e morale. Radici bibliche dell'agire cristiano (11 de Maio de 2008). O Sínodo dos Bispos realizado entre 5 e 26 de Outubro de 2008 foi dedicado ao tema "A Palavra de Deus na vida e na missão da Igreja".

${ }^{35}$ A Vulgata apareceu em edição revista com o título Nova Vulgata Bibliorum Sacrorum Editio em 1979. 
A versão da Bíblia a partir dos originais passou a constituir uma preocupação dos responsáveis das diversas Igrejas. A Bible de Jérusalem (1948-54) grangeou enorme êxito por todo o lado, tendo sido feitas traduções para outras línguas ${ }^{36}$.

De grande significado se revestiu em 1943 a encíclica de Pio XII Divino afflante Spiritu que trata do método histórico-crítico, do sentido literal do texto bíblico, dos géneros literários, do sentido espiritual da tradição da Bíblia e de outros temas de relevante interesse para a exegese bíblica ${ }^{37}$.

O grande historiador Roger Aubert apresenta três características da exegese moderna: o uso sempre maior do método histórico-crítico; o cuidado de não reduzir a exegese a um estudo filológico e arqueológico, mas de valorizar o alcance religioso ou teológico; e a dialéctica dos intérpretes alegóricos e literalistas.

Na Alemanha foram editados vários comentários bíblicos quer por católicos quer por protestantes. Em França destacou-se L.C. Fillion com um comentário em 8 vols., com a versão e análise de toda a Bíblia (1888-1915). Também é de referir o importante Dictionnaire de la Bible em 10 vols. (1912-1922) e depois o Supplément a partir de 1926. Por esse tempo tornaram-se bastante frequentes as disputas à volta de Renan e de Loisy e de outros escritores racionalistas quanto à essência do cristianismo e das suas fontes ${ }^{38}$.

Na Itália sobressaiu Giuseppe Ricciotti com História de Israel, Vida de Jesus Cristo, Paulo Apóstolo, obras que revelam a profunda preparação do autor. Em Espanha distinguiram-se Bover-Cantera, Nácar-Colunga, entre outros. Entre nós é de realçar o labor dos padres capuchinhos.

Também muito significou para o despertar do movimento ecuménico e do diálogo com as outras religiões a renascença patrística. Podemos considerar como ponto de partida no séc. XIX o trabalho de cariz apologético de Johann Adam Moehler ${ }^{39}$. Antes a Patrística era vista como serva da teologia; apoiava-se

\footnotetext{
36 Vid. nota 30.

${ }^{37}$ De então para cá têm sido publicados vários documentos eclesiásticos sobre a Sagrada Escritura.

${ }^{38}$ Joseph Ernest Renan (1823-1892), escritor, filósofo, filólogo e historiador francês, escreveu várias obras de índole racionalista. - Alfred Firmin Loisy (1857-1940) com as posições tomadas a favor do modernismo entrou em conflito com a Igreja. Os seus livros foram condenados pelo Vaticano e ele foi excomungado.

39 Johann Adam Moehler (1796-1838), teólogo católico, escreveu, entre outros Die Einheit in der Kirche oder das Princip des Katholicismus, Tubinga, 1825; Athanasius der Grosse u.d. Kirche seiner Zeit, 2 vols., Mogúncia, 1827; Symbolik, oder Darstellung der dogmatischen Gegensätze der Katholiken u. Protestanten nach ihren öffentlichen Bekenntnisschriften, ibidem, 1832, 8. ${ }^{a}$ ed., 1871-1872; Neue Untersuchungen der Lehrgegensätze zwischen den Katholiken u. Protestanten, 1834; Gesammelte Schriften u. Aufsätze, editada por Döllinger, 1839. - Vid. Michael Hardt, "50 Jahre Johann-Adam-Moehler-Institut für Ökumenik in Paderborn", in Jahrbuch für mitteldeutsche Kirchen- und Ordensgeschichte, Heiligenstadt, vol. 03.2007, p. $281-287$.
} 
em argumentos da Bíblia, da Patrística e da razão para sustentar a verdade católica. Agora a Patrística passou a ser tomada como ciência autónoma.

Entre os grandes instrumentos de trabalho salientem-se os de Migne e as edições dos Maurinos ${ }^{40}$. O Corpus de Berlim, o Corpus de Viena e o Corpus de Lovaina, bem como a edição das literaturas siríaca, copta, arménia, etíope, árabe na Patrologia Orientalis representaram um progresso de enorme alcance. Refira-se ainda o Corpus Christianorum, a Clavis Patrum Latinorum a Clavis Patrum Graecorum.

Para a crítica textual e a análise filológica e gramatical passou a dispor-se, entre outros, de A Patristic Greek Lexicon de G. W. H. Lampe e do Dictionnaire latin-français des auteurs chrétiens de Blaise e H. Chirat. O Reallexikon für Antike und Christentum (Leipzig, 1941), completado pelo Jahrbuch für Antike und Christentum, prestou valiosos serviços aos investigadores e aos estudiosos.

Para o grande público apareceu desde 1942 a colecção Sources chrétiennes, sob a direcção de de Lubac e Daniélou para o estudo das fontes cristãs antigas e medievais ${ }^{41}$. Aliás os textos do cristianismo primitivo têm conhecido igualmente diversas traduções noutras línguas.

O alcance teológico da renovação patrística está bem patente nos trabalhos de F. X. Funk (1840-1907), P. Batiffol (1861-1929), J. Lebreton (1873-1956), G. Bardy (1881-1955). Hans Urs von Balthasar (1905-1988), Jean Daniélou (1905-1974), Henri de Lubac (1896-1991); os três últimos participaram no Vaticano II.

Como grandes enciclopédias teológicas temos hoje a Theologische Realenzyklopädie, o Lexikon für Theologie und Kirche, Die Religion in Geschichte und Gegenwart, o Dictionnaire d'Archéologie chrétienne et de

${ }^{40}$ Jacques Paul Migne (1800-1875), sacerdote francês, editou sem custos significativos diversas obras com o fim de divulgar a cultura católica. Entre elas contam-se o Scripturae sacrae cursus completus em 28 vols, 1840-5; a Collection des auteurs sacrés (100 vols., 1846-8); a Encyclopédie théologique (171 vols., 1844-6). Mas as que lhe granjearam mais fama foram a Patrologia Latina em 221 vols. (1844-5) e a Patrologia Graeca, primeiro em latim e depois em grego com versão latina (85 vols., 1856-7; 165 vols., 1857-8). - Vid. Claude Langlois e François Laplanche, La Science catholique: 'L'Encyclopédie théologique' de Migne (1844-1873) entre apologétique et vulgarisation, Paris, 1992.

${ }^{41}$ O papa no passado dia 8 de Novembro de 2009 atribuiu o "Prémio internacional Paolo VI", que "L’Osservatore Romano" designa de "Nobel católico", à colecção francesa "Sources Chrétiennes". Esta colecção tem vindo a editar os principais textos dos fundadores do cristianismo, os Padres da Igreja (textos gregos, latinos e orientais da antiguidade, com alguns prolongamentos medievais) na língua original acompanhados da versão francesa. É a primeira vez que o prémio é concedido a uma obra colectiva. No passado foi atribuído ao teólogo Hans Urs von Balthasar, ao compositor e organista Olivier Messiaen, ao teólogo luterano Oscar Cullmann, ao fundador da Comunidade da Arca, Jean Vanier, e ao filósofo Paul Ricoeur. 
Liturgie, o Dictionnaire d'Histoire et de Géographie ecclésiastiques, o Dictionnaire de Spiritualité, o Dictionnaire de Théologie catholique, etc.

\section{O diálogo religioso}

Hoje é uma expressão corrente. Mas o conceito de diálogo começa em 1945. No Ocidente, a Igreja reformada dos Países Baixos recorre ao termo diálogo ou conversação (gesprek) numa declaração de 1947 para designar a relação teológica da Igreja com Israel, entendido este no sentido de povo judaico. O diálogo com Israel distingue-se da acção missionária com as outras crenças.

Relativamente ao Islão, que hoje se tornou uma força religiosa importante na Europa, a primeira obra que fala de diálogo é a do pastor Henri Nusslé (1949). Em 1955, o uso já está consagrado num texto de J. Spencer Trimingham sobre a Inglaterra:

«Utilizamos este termo «diálogo» na sua acepção continental moderna de encontro construtivo entre cristãos e muçulmanos, desprovida de considerações polémicas ou de vontade de conversão; um encontro no respeito recíproco e a compreensão mútua da fé do outro, com o cuidado de encontrar uma base comum e um compromisso a favor do bem-estar da sociedade no seu conjunto» ${ }^{42}$.

A expressão «encontro construtivo» é importante. Estávamos habituados à ideia de superioridade de uma religião sobre as outras e ao princípio «extra ecclesia nulla salus», especialmente nas polémicas anti-judaicas e anti-muçulmanas $^{43}$.

O primeiro grande acontecimento neste âmbito foi o Parlamento Mundial das Religiões que teve lugar em 1893 em Chicago por ocasião dos 400 anos da evocação da chegada de Colombo ao continente americano. O seu fim era unir as religiões contra todas as formas de irreligião, fazer da regra de ouro (Mt. 7, 12) a base da união e apresentar ao mundo (...) a unidade essencial das numerosas religiões nas boas acções da vida religiosa. Entre os textos publicados, salientam-se os de F. Max Müller e Cornelius P. Tiele, mas o mais importante é o do swámi Vivekananda (1863-1902), discípulo de Ramakrisna ${ }^{44}$.

${ }^{42}$ J. S. Trimingham, The Christian Church and Islam in West Africa, Londres, 1955, p. 45. Escreveu várias obras sobre o Islão.

${ }^{43}$ Vid. F. Vernet, "Juifs (Controverses avec), in Dictionnaire de Théologie Catholique, t. 8, 1925, col. 1870-1914.

${ }^{44}$ Swami Vivekananda (1863-1902), nascido Narendranath Dutta, monge, ioga e filósofo hindu, é considerado um dos mais célebres e influentes líderes espirituais do hinduísmo moderno, sobretudo da filosofia veda. Foi pioneiro da sua divulgação no Ocidente e inspirador do movimento do espiritualismo universalista. Principal discípulo de Ramakrishna Paramahamsa, foi o fundador da Ordem Ramakrishna e da organização monástica Sri Ramakrishna Math. 
Mas não se discutiu o desafio da modernidade, nem da unidade face à hostilidade ou à indiferença religiosa. Surgiram contudo diversas iniciativas que obtiveram grande impacto.

O estudo das religiões conheceu entre 1900 e 1950 forte incremento. Em 1900, a Exposição Universal de Paris incluiu o primeiro congresso internacional de história das religiões. Foi o primeiro de uma longa série que continuou depois. A primeira cadeira sobre o tema surgiu em 1873 na faculdade de teologia de Genebra a que se seguiram outras universidades. Entre os nomes de professores célebres conta-se Nathan Söderblom (1866-1931) que no seu leito de morte disse: «Sei que Deus está vivo; posso prová-lo pela história da religião».

Outra grande figura foi Rudolf Otto (1869-1937) que ensinou história das religiões na faculdade de teologia de Marburgo $^{45}$.

Papel relevante desempenhou a International Association for the History of Religions entre 1950 e 1970. Especialistas e simples curiosos acorriam aos congressos e sessões de estudo e liam o que se ia escrevendo para se ilustrarem acerca das religiões e da sua importância.

No campo propriamente católicoé sempre bom lembrar que foi no pontificado de Leão XIII (1878-1903) que se colocaram "lato sensu" os fundamentos do pensamento católico sobre o ecumenismo ${ }^{46}$. Muitos obstáculos tiveram de ser desfeitos, pois estava-se numa fase difícil da vida da Igreja, nomeadamente por causa do modernismo. Em 1918, Roma fez saber a Söderblom que não concordava que a Igreja ficasse em igualdade com as outras confissões cristãs. Não podiam ser discutidos pontos intocáveis. O Santo Ofício publicou um decreto que proibia aos católicos que participassem em congressos ecuménicos

45 Rudolf Otto (1869-1937), eminente teólogo luterano alemão, foi um dos mais famosos investigadores de história comparada das religiões. A sua principal obra é Das Heilige. Über das Irrationale in der Idee des Göttlichen und sein Verhältnis zum Rationalen (1917. O sagrado é o numinoso (de numen, divindade), o que não se vê nem experimenta, que é irracional. É mistério, tremendo, fascinante. Lembra Kant com a sua ideia de noumenon. Teve grande influência em Paul Tillich, Gustav Mensching, Mircea Eliade (Das Heilige und das Prophane, trad. port. O sagrado e o profano), Martin Heidegger, Leo Strauss, John A. Sanford, Hans-Georg Gadamer, Max Scheler, Ernst Jünger, Joseph Needham e Hans Jonas. - Mircea Eliade (Bucareste, 1907-Chicago, 1986), historiador e romancista romeno naturalizado norte-americano, é um dos mais importantes e influentes historiadores e filósofos das religiões da contemporaneidade. Várias das suas obras estão traduzidas para português.

${ }^{46}$ Nas suas diversas encíclicas como na Aeterni Patris (4 de Agosto de 1879) mostrou o seu grande empenho em promover os estudos eclesiásticos. Deve-se-lhe a renovação do tomismo. Elevou ao cardinalato John Henry Newman e interessou-se bastante com as relações com o anglicanismo. A abertura dos Arquivos do Vaticano (1883) foi outro acontecimento importante. Na ocasião publicou uma encíclica em que fala da importância dos estudos históricos e afirma que a Igreja não deve ter medo da verdade. À frente dos Arquivos e da Biblioteca do Vaticano estiveram figuras eminentes como Hergenröther, Denifle e Ehrle. 
sem permissão da Santa Sé. Mas em 1952 autorizou que quatro observadores participassem na conferência de Lund. As hesitações eram frequentes, aliás como ainda hoje acontece muitas vezes. A questão que se colocava era: apologia ou renovação autêntica interna que importava promover? O ecumenismo é mais uma atitude espiritual, uma nova maneira de ser cristão, diziam os fautores da aproximação.

As conversações de Malines (1921-1925), com o placet de Pio XI, em que pontificaram Mercier, Portal e Halifax, trataram da reunião da Igreja católica com a anglicana, enquanto Paul Couturier e Dom Lambert Beaudin se dedicavam mais ao trabalho com os reformados. $\mathrm{O}$ aspecto espiritual era considerado fundamental. Dom Beauduin fundou em 1925 o priorado de Amay, transferido em 1939 para o actual mosteiro de Chevetogne, inteiramente consagrado à unidade, com a revista Irenikon. Intimamente relacionado com isto devemos falar de uma nova consciência eclesiológica que chamava a atenção para a ideia de corpo místico, sacramento original, mistério, povo de Deus, comunhão e comunidade na sequência das investigações patrísticas e medievais. Assim se pretendia evitar sobrevalorizar os aspectos externos ou estruturais que Trento e a Contra-Reforma tanto haviam inculcado.

Em 1937, Yves Congar inaugurou nas Edições do Cerf a colecção "Unam Sanctam" com o seu livro Chrétiens désunis, principes d'un oecuménisme catholique. É a melhor colecção em francês sobre eclesiologia com relevo para o ecumenismo. O padre Dumont fundou o Centre Istina (Paris) com a revista Istina que primeiro tratou do estudo do cristianismo oriental e depois do ecumenismo propriamente dito (1948). Na Alemanha, lembramos o movimento Una Sancta, criado por M.-J. Metzger e H. Hoffman, o Instituto Johann Adam Moehler (Paderborn), o círculo do professor J. Lortz, o Instituto Ecuménico de Tubinga, etc. Na Holanda, o professor J. Willebrands criou em 1952 uma conferência católica para as questões ecuménicas. Em Roma, temos desde 1947 o Centro Unitas e a revista do mesmo nome, que foi dirigida por Charles Boyer. A questão que se punha era a do retorno dos irmãos separados ou simplesmente dos encontros, sendo esta tese defendida por P. Lambert.

O Conselho Ecuménico das Igrejas com sede em Genebra foi criado em 1948 incluindo mais de 300 Igrejas cristãs do mundo inteiro. A Igreja católica não está integrada, mas mantém com ele um diálogo permanente.

As Assembleias de Amsterdão (1948), Evanston (1954), Nova Delhi (1961), Uppsala (1968), Nairobi (1968), Vancouver (1983) e Camberra (1991), Harare (1998) e Porto Alegre (2006) manifestaram uma grande abertura ao diálogo ecuménico e uma atenção especial aos problemas da humanidade: educação, totalitarismo, racismo, opressão económica, militarismo, guerras, armas 
nucleares, fome, emigração, etc. A pessoa humana era vista como o ponto de interesse fundamental. Três palavras definem essas actividades: missão, unidade e serviço.

\section{O concílio Vaticano II (1962-1965) e a teologia ecuménica e das religiões}

Quanto à Igreja católica, entre outros factos, lembremos o papel fundamental de João XXIII e a criação do Secretariado para a Unidade dos Cristãos (1960) e o concílio ecuménico Vaticano II (11 de Outubro de 1962-8 de Dezembro de 1965). Paulo VI, João Paulo II e agora Bento XVI prosseguiram o caminho do diálogo e do encontro com as várias confissões cristãs, com o judaísmo, o islamismo e as outras religiões não cristãs. Na memória de todos está o encontro de Assis pela paz em 27 de Outubro de 1986 promovido por João Paulo II. Lembremos apenas o texto "Noi ricordiamo" que é uma reflexão sobre a Shoah. Este papa e Bento XVI nas suas viagens pastorais e em documentação diversa muito têm inculcado a valorização do diálogo com os Hebreus e também com o Islão.

De especial importância para o ecumenismo católico moderno é a encíclica de Pio XII Mystici Corporis (1943) que trata do mistério da Igreja, visível e invisível, do amor e do direito ${ }^{47}$.

O Vaticano II com a declaração Unitatis redintegratio sobre o ecumenismo e com o decreto Dignitatis humanae sobre a liberdade religiosa abriu novos horizontes no campo da inter-religiosidade. Na Declaratio de ecclesiae habitudine ad religiones non christianas, mais conhecida pelo documento Nostra aetate, sobre as relações da Igreja com as religiões não cristãs, dáse especial ênfase ao judaísmo, ao islamismo, ao budismo e ao hinduísmo. O termo colloquium aparece várias vezes nos textos conciliares.

Outros documentos relacionados com aqueles são o Ad gentes sobre a actividade missionária da Igreja ${ }^{48}$, a constituição Lumen gentium que menciona explicitamente os judeus, os muçulmanos e os outros crentes, para afirmar que ninguém está excluído da salvação; e a constituição Gaudium et spes sobre a Igreja neste mundo que diz a certa altura: «No que nos respeita, o desejo dum tal diálogo, conduzido pelo único amor da verdade e também com a prudência requerida, não exclui ninguém».

47 Em 25 de Maio de 1995 João Paulo II assinou a encíclica Ut unum sint que teve grande eco nos meios ecuménicos.

48 Bernhard Blumenkranz, Juifs et chrétiens dans le monde occidental, 430-1096, Paris-Lovaina, 2006; Dictionnaire Encyclopédique du Judaïsme, op. cit. 
O Vaticano II pretendeu apresentar a Igreja como instrumento de salvação e como povo de Deus e como comunidade de salvação. Os contributos de Koster, Semmelroth, Journet, Congar e de Lubac revelaram-se sumamente importantes neste domínio.

Era a passagem do ecumenismo confessional para o ecumenismo ecuménico que muito ficou a dever ao regresso à Bíblia e à Patrística e ao indiscutível papel de alguns teólogos protestantes ${ }^{49}$. Outros nomes de destaque são H. Bouillard, R. Marlé, O. Cullmann, R. Kittel, o anglicano C. H. Dodd e os católicos Congar $^{50}$, de Lubac, Lyonnet e Quasten.

Não existe só um ecumenismo oficial ou institucional; há também um ecumenismo espiritual e prático e um ecumenismo doutrinal ou teológico. No seu último curso de teologia ecuménica no Instituto Católico de Paris, a que deu o título de "Diversidade e comunhão", o grande pensador Yves Congar excluiu o caminho do retorno dos cristãos não católicos ao seio da Igreja bem como o adiamento da unidade para os tempos escatológicos. Para ele há que conjugar a catolicidade com diversidade e o pluralismo. Para isso cada confissão religiosa deve reavaliar a doutrina que professa à luz dos condicionamentos históricos em que a mesma foi elaborada. A título de exemplo referimos o que se passa com o problema da justificação com os protestantes.

Também na mesma linha se situam Heinrich Fries e Karl Rahner em Einigung der Kirchen, reale Möglichkeit (1983) ao falarem de uma diversidade reconciliada, pois as formas separatórias são a expressão de diverso tipo no âmbito de um património comum. Perderam o seu carácter de "anti" e adquiriram a sua consistência positiva. Este modelo é também adoptado por Oscar Cullmann na sua síntese ecuménica "A unidade através da diversidade" (1986). Edmund Schlink em Ökumenische Dogmatik fala de "renovação coperniciana": «Não devemos imaginar que as outras Igrejas se movem à volta da nossa, como se esta fosse o centro (...); é preciso, pelo contrário, reconhecer que, ao lado das outras comunidades, também gravitamos como se fôssemos planetas à volta de Cristo, sol do qual recebemos a luz». Para Cullmann a unidade estruturante poderia ser o Conselho Ecuménico das Igrejas com a adesão da Igreja de Roma. E assim se chegaria koinonía de todos os cristãos em ordem à missão $0^{51}$.

49 Obras como o Theologisches Wörterbuch zum Neuen Testament e a Dogmática de K. Barth revestem-se de elevado significado.

50 Yves M.-J. Congar, Chrétiens en dialogue. Contributions catholiques à l'Oecuménisme, Paris, 1964; Inos Biffi, Verità cristiane nella nebbia della fede, Milão, 2005.

${ }^{51}$ Koinonía é um conceito teológico que trata da comunhão eclesial e dos vínculos por esta gerada entre os membros da Igreja e Deus, revelado em Jesus Cristo e actuante na história por meio do Espírito Santo. 
Estabeleceram-se princípios teológicos do ecumenismo actual, falou-se de enigma sem teoria e de pluralidade como desejada por Deus e deram-se explicações filosófico-místicas. Karl Barth escreveu: «Se nós pudéssemos deduzir a pluralidade das Igrejas de uma unidade que seria o seu princípio, se nós pudéssemos desenvolver de uma certa forma a verdade da Ecclesia sancta catholica e da communio sanctorum, por exemplo segundo o esquema da tese-antítese-síntese, e a partir daí concluir que a coexistência e a oposição de Roma e Constantinopla, de Wittenberg e de Genebra, do episcopalismo e do presbiterianismo, do protestantismo dos reformadores e dos modernistas, e de todas as outras oposições que se foram produzindo, que são necessárias, não haveria mais drama».

O passo seguinte era este: como considerar os grupos separados na óptica da Igreja católica? Que lugar corresponde à Igreja entre os outros grupos e Igrejas cristãs? Houve quem defendesse o método indutivo: a partir de dados sociológicos, históricos e psicológicos pretende-se chegar a uma teologia ecuménica mais clara e mais decisiva sobre a Palavra de Deus. Não é só o problema da unidade da Igreja; ela é também considerada como um caminho para a unidade no sentido mais largo possível.

No que todos concordam é que há três instrumentos de trabalho imprescindíveis: a oração, o retorno às fontes e o diálogo, sendo este último muito apreciado nos últimos tempos e com resultados deveras positivos ${ }^{52}$.

No que respeita ao diálogo com os Judeus devemos lembrar a grande figura em todo este processo do cardeal Agostinho $\mathrm{Bea}^{53}$; o encontro do historiador Jules Isaac (1877-1963) com o papa João XXIII para que a questão do judaísmo fosse tratada pela Igreja ${ }^{54}$; e Jacob Neusner, autor de vários estudos

${ }^{52}$ René Girault oferece um excelente panorama da actividade ecuménica durante os 20 anos pós-conciliares em Dialogues aux frontières de l'église, Paris, 1965.

53 Agostinho Bea, SJ (1881-1968), ilustre teólogo, biblista e arqueólogo, foi o primeiro presidente do Secretariado para a Promoção da Unidade Cristã. Grande investigador e ecumenista, teve enorme influência nas relações com os outros cristãos e, em particular, com os Judeus durante o Vaticano II. Deve-se-lhe a redacção do documento Nostra Aetate.

54 Jules Isaac (1877-1963), pioneiro das Amizades Judéo-cristãs, tentou encontrar as causas do anti-semitismo. Publicou Jésus et Israël, redigido durante a guerra, que depois inspirou a Carta de Seelisberg. A conferência de Seelisberg é uma conferência internacional extraordinária que teve lugar na aldeia de Seelisberg (Suíça) de 30 de Julho a 5 de Agosto de 1947, para estudar as causas do anti-semitismo cristão. Estiveram presentes 70 personalidades de 17 países, entre os quais 28 Judeus como Jules Isaac, o rabino Jacob Kaplan, grande rabino de França, o rabino Alexandre Safran, o grande rabino da Roménia, o escritor Josué Jéhouda, de Genebra, o professor Selig Brodetzki, presidente do Conselho representativo dos Judeus de Inglaterra; 23 protestantes; e 9 católicos como os padres Marie-Benoît Péteul, Calisto Lopinot, Charles Journet, Jean de Menasce, Paul Démann. Foi elaborada uma lista de 10 pontos sobre aspectos negativos e positivos que devem conduzir as relações entre Judeus e Cristãos. Logo o primeiro diz: «É o mesmo Deus que nos fala a todos no Antigo e no Novo Testamento». Em 1949, intervém junto de Pio XII para que seja 
famosos como A Rabbi talks with Jesus. An Intermillenial Interfaith Exchange, N. Y., $1993^{55}$.

Um nome célebre do diálogo religioso com o mundo árabe e judaico é André Chouraqui (1917-2007), autor de uma vasta e valiosa obra em que aborda o problema das relações do judaísmo, do cristianismo e do islamismo ${ }^{56}$.

No Vaticano funcionam hoje alguns Conselhos que têm a seu cargo as relações com as outras religiões: o Conselho para a Promoção da Unidade dos Cristãos com uma secção especial para os Judeus, a Comissão para as Relações Religiosas com o Judaísmo; e o Conselho Diálogo Inter-religioso; e podemos acrescentar o Conselho para a Cultura. Os documentos por eles produzidos revestem-se de enorme relevância para um melhor conhecimento e aprofundamento das questões religiosas e culturais que o diálogo proporciona.

Um documento importante que não podíamos omitir é o Dabru Emet («Dizei a verdade») sobre as relações entre o judaísmo e o cristianismo que foi assinado por mais de 220 rabinos e intelectuais judeus a título pessoal e não colectivo nem representando qualquer corrente. Foi redigida nos Estados Unidos por iniciativa do National Jewish Scholars Project e apareceu pela primeira vez em Setembro de 2000.

A declaração chama a atenção para as diferenças teológicas entre o judaísmo e o cristianismo tendo em linha de conta os pontos comuns. Não pretende ser um documento oficial. Foi objecto de vários debates.

Passando ao tema da teologia das religiões, não há dúvida que foi Hans Küng um dos que mais se empenharam no assunto ${ }^{57}$. Entendeu que havia que passar

revista a oração de $6 .{ }^{\text {a }}$ feira-santa pro perfidis judaeis, com o que concordou João XXIII, mesmo antes do concílio Vaticano II. O actual papa Bento XVI alterou para: «Oremus et pro Iudaeis. Ut Deus et Dominus noster illuminet corda eorum, ut agnoscant Iesum Christum salvatorem omnium hominum». Este gesto foi o ponto de partida para uma forte amizade com João Paulo II. - Vid. Menahem Macina, "Le rôle de Paul Démann à Seelisberg", in Revue Sens, 1999 no 51, pp. 434-439; Alexandre Safran, "Mes souvenirs de la Conférence de Seelisberg (1947) et de l'abbé Journet", in Judaïsme, anti-judaïsme et christianisme: Colloque de l'Université de Fribourg, 16-20 mars 1998, Paris, 2000, pp. 13-22; Pierre Mamie, "La Charte de Seelisberg et la participation du Cardinal Journet", in Judaïsme, anti-judaïsme et christianisme: Colloque de l'Université de Fribourg, 16-20 mars 1998, Paris, 2000, pp. 23-34; Paul Démann, "De Seelisberg à Vatican II", in Revue Sens, 2006, pp. 77-84.

55 Jacob Neusner, nascido em 1932, é um universitário Americano especialista em Judaísmo. De grande interesse é o seu livro Der Jude Jesus von Nazareth: zum Gespräch zwischen Jacob Neusner und Papst Benedikt XVI, editado por Achim Buckenmaier, Rudolf Pesch e Ludwig Weimer, Paderborn, 2008. Joseph Ratzinger (Bento XVI) no seu livro Jesus von Nazareth - Von der Taufe im Jordan bis zur Verklärung refere-se em termos de muita simpatia para com Neusner. Rudolf Pesch acaba de publicar o livro Juden und Christen - ein einziges Volk Gottes?, Düsseldorf, 2009.

${ }^{56}$ Viveu entre 1917 e 2007.

${ }^{57}$ Alguns temas dos seus livros mais célebres: a justificação (doutrina de Karl Barth e uma interpretação católica (1957), a reforma da Igreja e a unidade dos cristãos (1960), a infalibilidade (1970 e 1973), a Igreja (1967), o que é ser cristão (1974), a existência de Deus (1978), a vida eterna (1982), o cristianismo e as 
do ecumenismo cristão (ad intra) para o ecumenismo global (ad extra). O livro de Thomas Kuhn, A estrutura das revoluções científicas $(1962)^{58}$, foi aplicado às ciências histórias e à teologia no que concerne à mudança de paradigma.

O tema do ecumenismo ad extra é desenvolvido por Hans Küng no Projecto de uma ética mundial (1990) que é uma teologia ecuménica para a paz: Não pode haver convivência humana sem um ethos mundial das nações; não pode haver paz entre as nações sem paz entre as religiões; não pode haver paz entre as religiões sem diálogo entre as mesmas» ${ }^{59}$.

Hans Küng responde depois a diversas questões que se colocam quanto ao problema da verdade. Nem a estratégia da fortaleza como se só a própria religião fosse a verdadeira; nem a estratégia da minimização como se a questão da verdade não interessasse; nem a estratégia do abraço como se se tratasse dum inclusivismo tolerante; mas sim uma estratégia ecuménica, segundo a qual qualquer religião tem os seus critérios específicos de verdade, mas que é chamada também a formular critérios ético-universais. As religiões não são meras filosofias ou visões do mundo, mas oferecem uma via de salvação.

Noutros tempos valia o axioma «extra ecclesiam nulla est salus» e estoutro «facienti quod est in se, Deus non denegat gratiam». Karl Barth na sua Dogmática fala de revelação/religião, pelo que a atitude negativa a respeito das religiões vinha ao de cima. Do lado católico começaram a aparecer autores que se propunham vincar os valores positivos das religiões não cristãs como preparação para a aceitação da fé cristã. Sobretudo Karl Rahner e Heinz Robert Schlette. O primeiro numa conferência feita em 1961 tratou do Cristianismo e Religiões não cristãs, incluída depois nos seus Escritos vários. Falou de cristãos anónimos. Schlette num importante volume da colecção «Quaestions Disputatae», Las religiones como tema de la teologia (1963) fala das religiões

religiões universais (1984) que é uma introdução ao diálogo com o islamismo, o hinduísmo e o budismo, etc.

${ }^{58}$ Título original The structure of scientific revolutions, reed. alemã Die Struktur wissenschaftlicher Revolutionen, Francoforte, 2007. Entre outros livros seus conta--se Reformierter Protestantismus vor den Herausforderungen der Neuzeit, Wuppertal, 2008.

${ }^{59}$ Também a UNESCO e outras organizações têm dado uma relevância particular ao tema do contributo das religiões para a concórdia entre os povos. Os papas Paulo VI, João Paulo II e Bento XVI tiveram importantes intervenções na ONU em que abordaram, entre outros, os temas da paz e do diálogo das religiões. O actual pontífice disse a certa altura do seu discurso, a 18 de Abril de 2008: «É próprio da natureza das religiões, livremente praticadas, o facto que possam autonomamente conduzir um diálogo de pensamento e de vida. Se mesmo a tal nível a esfera religiosa é mantida separada da acção política, provêm grandes benefícios para os indivíduos e para a comunidade. Por outro lado, as Nações Unidas podem contar com os resultados do diálogo entre as religiões e colher fruto da disponibilidade dos crentes em colocar as próprias experiências ao serviço do bem comum. A sua tarefa é a de propor uma visão da fé não em termos de intolerância, de discriminação e de conflito, mas em termos de respeito total pela verdade, pela coexistência, pelos direitos e pela reconciliação». 
como caminhos de salvação. A salvação realiza-se com a realização da epifania da glória de Deus. O documento Nostra Aetate do Vaticano II apela para que os cristãos colaborem com os adeptos das outras religiões e «reconheçam, conservem e promovam aqueles valores espirituais e sócio-culturais que nelas existem».

Outros autores famosos são Paul Knitter e Richard Niebuhr ${ }^{60}$ que abordam quatro atitudes: «Cristo contra as religiões», «Cristo nas religiões», «Cristo para além das religiões» e «Cristo com as religiões» (teocentrismo com cristologia não normativa, ou seja, teocentrismo pluralista). E ainda John Hick em Deus e o universo das fés (1973) e em Deus tem muitos nomes (1980). É a passagem de um paradigma cristocêntrico para um paradigma teocêntrico.

Referimos ainda o teólogo católico Raimon Panikkar que em Il dialogo intrareligioso e em Cristo desconocido del hinduísmo (1964) fala de fé e crença, de diálogo inter-religioso e de diálogo intra-religioso, este interior e aberto ao outro, capaz de atingir a dimensão profunda da fé6 ${ }^{61}$; e o teólogo protestante índio Stanley Samartha com Courage for Dialogue. Ecumenical Issues in Inter-Religious Relationships (WCC Geneva 1981) e One ChristMany Religions. Toward a Revised Christology (Nova York, 1991) que trata da necessidade de passar da cristologia pura para uma cristologia teocêntrica relacional $^{62}$; o teólogo católico americano Paul Knitter com No Other Name? A Critical Survey of Christian Attitudes Toward the World Religions (ibidem, 1985) aborda o problema do teocentrismo pluralista que propõe uma teologia pluralista das religiões ${ }^{63}$.

Mas uma teologia pluralista das religiões como foi defendida pelos referidos autores põe de lado o problema da identidade do cristianismo e da verdade ${ }^{64}$.

O jesuíta francês Jacques Dupuis em Jésus-Christ à la rencontre des religions, (Paris, 1989) e Vers une théologie chrétienne du pluralisme religieux

${ }^{60}$ Niebuhr nasceu em Wright City, Missouri, filho de Gustav Niebuhr, ministro do Sínodo Evangélico da América do Norte; viveu entre 1894-1962.

${ }^{61}$ Raimon Panikkar (1918-) é um célebre especialista do diálogo inter-religioso.

${ }^{62}$ Nasceu em 1920, filho de um pastor da Missão Evangélica de Basileia. Viveu na sociedade pacífica pluri-religiosa de Karnataka (Sul da Índia) e interessou-se pelo problema das religiões. Confessou um dia: "Christian life can be lived pluralistically".

${ }^{63}$ Paul F. Knitter tornou-se mundialmente conhecido pelo seu pluralismo religioso. Juntamente com o seu colega o filósofo protestante, de história das religiões, John Hick, foi duramente criticado pelo então cardeal Joseph Ratzinger.

${ }^{64}$ Vid. Bernd Jochen Hilberath, Ivana Noble, Johannes Oelemann et alii (ed.), Ökumene des Lebens als Herausforderung der wissenschaftlichen Theologie: Tagungsbericht der 14. Wissenschaftlichen Konsultation der Societas Oecumenica $=$ Ecumenism of life as a challenge for academic theology: proceedings of the 14th Academic Consultation of the Societas Oecumenica, Francoforte, 2008. 
(ibid., 1997) analisa a relação de Cristo com as outras crenças numa perspectiva de abertura e aproximação ${ }^{65}$.

Hans Küng em Theologie im Aufbruch. Eine ökumenische Grundlegung (Munique, 1987), que se pode considerar como uma teologia para o $3^{\circ}$. milénio, em Projekt Weltethos (Munique-Zurique, 1990) e noutros livros seus aborda o tema da teologia das religiões não cristãs sob a perspectiva cristã ao serviço de uma teologia ecuménica para a paz. Exclui o ateísmo e o relativismo, o exclusivismo e o inclusivismo. A questão da verdade que é complexa não pode ser posta de parte. Ela é ética, religiosa e especificamente cristã. Como afirma, uma religião é verdadeira e boa quando é humana, quando protege e promove a humanidade. Quando permanece fiel à sua própria origem e ao seu cânon: o seu ser autêntico, a sua Escritura ou a sua figura normativa. Na teoria e na prática deve deixar transparecer o espírito de Jesus Cristo. Ética e religiosamente falando, muitas religiões podem afirmar-se como verdadeiras; mas do ponto de vista existencial só uma é verdadeira e assim para o cristão só o cristianismo é verdadeiro. As outras são verdadeiras sob condição. O critério ecuménico é duplo: o critério do Humanum e o critério especificamente cristão, o Humanum e o Evangelho. Mas o Evangelho e as religiões estão ao serviço do Humanum, do que segue que o Humanum é critério ecuménico fundamental.

$\mathrm{O}$ séc. XX assistiu à abertura das teologias confessionais à teologia ecuménica e à teologia das religiões. Estamos numa época ecuménica e planetária em que, segundo Johann Baptist Metz se exprime «uma Igreja mundial enraizada em numerosas culturas e neste sentido policêntrica, na qual, de resto, a herança europeia e ocidental não está destinada a ver-se reprimida, mas a ser de novo solicitada e colocada em desafio». A teologia é desta feita confrontada com a lógica da Incarnação e da Redenção, na defesa e ao serviço do Humanum, como diz Gibellini. O valioso património legado pelas várias religiões e culturas exige a interpretação de todas como forma de enriquecimento da Humanidade.

Na passagem do $10^{\circ}$ aniversário da encíclica Fides et Ratio (1998) de João Paulo II o actual pontífice afirmou: «Lê-se na Encíclica que é necessário ter confiança nas capacidades da razão humana e não propor metas demasiado modestas: "É a fé que impele a razão a sair de todo o isolamento e a arriscar de bom grado por tudo aquilo que é belo, bom e verdadeiro. Assim, a fé faz-se

${ }^{65}$ Dupuis foi censurado pela Congregação para a Doutrina da Fé, mas o papa João Paulo II veio a reconhecer o seu pioneirismo no significado das outras religiões de acordo com o plano divino de salvação da humanidade. Faleceu em Roma a 28 de Dezembro de 2004. - A Declaração Dominus Iesus é um documento sobre a unicidade e a universalidade salvífica de Jesus Cristo e a doutrina da Igreja. Foi emitido pela Congregação para a Doutrina da Fé, no dia 6 de Agosto de 2000, assinado pelo então prefeito da Congregação, o Cardeal Joseph Ratzinger. 
defensora convicta e convincente da razão" (n. 56). De resto, a passagem do tempo manifesta quais foram as metas que a razão, impelida pela paixão pela verdade, soube alcançar. Quem poderia negar a contribuição que os grandes sistemas filosóficos ofereceram para a autoconsciência do homem e para o progresso das várias culturas? Elas, além disso, tornam-se fecundas quando se abrem à verdade, permitindo que quantos nela participam alcancem objectivos que tornam cada vez mais humana a vivência social. A busca da verdade dá os seus frutos principalmente quando é sustentada pelo amor à verdade. Agostinho escrevia: "Aquilo que se possui com a mente, obtém-se conhecendo-o, mas nenhum bem é conhecido perfeitamente se não se ama de modo perfeito" (De diversis quaestionibus, 35,2$) »$.

E na sua última encíclica, Caritas in veritate, de 29 de Junho de 2009, o papa Bento XVI escreveu: «Existem, em todas as culturas, singulares e variadas convergências éticas, expressão de uma mesma natureza humana querida pelo Criador e que a sabedoria ética da humanidade chama lei natural. Esta lei moral universal é um fundamento firme de todo o diálogo cultural, religioso e político e permite que o multiforme pluralismo das várias culturas não se desvie da busca comum da verdade, do bem e de Deus». 